\title{
Polychaetes of the soft bottoms of the Straits of Magellan collected during the Italian oceanographic cruise in February-March 1991*
}

\author{
MARIA CRISTINA GAMBI and SIMONE MARIANI \\ Stazione Zoologica “Anton Dohrn”, Laboratorio di Ecologia del Benthos, I-80077 Ischia (Napoli, Italy); \\ Fax: +3981 984201; e-mail: gambimc@alpha.szn.it
}

\begin{abstract}
SUMMARY: Species composition, distribution and biogeography of polychaetes collected from the soft bottoms of the Straits of Magellan (South America) in February-March 1991 are reported. In 16 benthic samples, collected with different tools (Charcot and triangular dredges, van Veen grab), a total of 1132 individuals belonging to 119 taxa of polychaetes were collected; only 49 of the taxa found have been determined at species level. Eighteen species were recorded for the first time in the Straits of Magellan. Species richness was relatively high considering both the number of individuals collected, and the taxa known from previous studies on the area (182 species). The biogeographical analysis, conducted only on the 49 taxa classified at the species level, showed the dominance of Magellan-Antarctic-Subantarctic species (M-An-S 50\%), followed by Magellan-American (M-Am 14\%), Magellan-Antarctic (M-An 12\%), Magellan-Subantarctic (M-S 6\%), Cosmopolitans (C 10\%), and also by a few species with disjunct distribution (D 8\%). Values of the Sørensen similarity index among stations were very low (below 0.30) with a few exceptions. Both number of species and of individuals were higher in the Atlantic sector of the Straits, especially at some stations characterized by heterogeneous mixed sediments (gravels and pebbles) and biogenic debris (mollusc thanatocoenosis). The high number of species recorded, coupled with low similarity values among stations, suggests that the soft bottoms of the Straits of Magellan show, at medium scale, a highly diversified mosaic of different biotopes. This can be due to various factors which are expected to vary along the wide geographic area investigated, such as the wide bathymetric range sampled, the type of sampling gears used, and last but not least the occurrence of many different environmental situations along the Straits.
\end{abstract}

Key words: Polychaetes, soft bottoms, biogeography, distribution, Straits of Magellan, South America, Subantarctic region.

RESUMEN: Poliouetos de fondos blandos en el Estrecho de Magallances Capturados durante la Campaña oceANOGRÁFICA ITALIANA EN FEBRERO-MARZO DE 1991. - En el presente trabajo se describen composición específica, distribución y biogeografía de los poliquetos recolectados en los fondos blandos del Estrecho de Magallanes (Sudamérica), durante los meses de febrero y marzo del año 1991. En 16 muestras bentónicas, recogidas con diferentes métodos (dragas Charcot, triangular y van Veen), se encontraron un total de 1132 individuos pertenecientes a 119 taxones de poliquetos. De éstos tan solo 49 han sido determinados a nivel de especie y a su vez 18 han resultado ser nuevas citas para el Estrecho de Magallanes. La riqueza específica encontrada fue relativamente alta, considerando tanto el número de individuos recolectados como los taxones conocidos gracias a estudios previos en el área (182 especies). El análisis biogeográfico, efectuado solamente sobre los taxones clasificados a nivel de especie (49), ha demostrado la dominancia de especies Magallano-Antártico-Subantárticas (M-An-S 50\%), seguida por especies Magallano-Americanas (M-Am 14\%), Magallano-Antárticas (M-An 12\%), Magallano-Subantárticas (M-S 6\%), Cosmopolitas (C 10\%) y también por especies de distribución disjunta (D 8\%). Los valores del índice de similaridad de Sørensen entre estaciones fueron muy bajos (inferiores a 0.3 ) salvo algunas excepciones. Tanto el número de especies como el número de individuos fueron más elevados en el sector atlántico del Estrecho, particularmente en algunas estaciones caracterizadas por sedimentos heterogéneos de tipo mixto (gravas y guijarros), y restos biogénicos (tanatocenosis de moluscos). El elevado número de especies descrito, combinado con los valores bajos de similaridad entre estaciones, sugieren que los fondos blandos del Estrecho de Magallanes presentan, a media escala, un mosaico altamente diversificado de biotopos diferentes. Esto puede ser debido a varios factores que son responsables de la variación a lo largo de la vasta área geográfica investigada, tales como el amplio rango batimétrico estudiado, el tipo de ins-

*Accepted December 4, 1998. 
trumentación de muestreo, y en último lugar pero no menos destacable, la presencia de muchas situaciones ambientales diferentes a lo largo del Estrecho.

Palabras clave: Poliquetos, fondos blandos, biogeografía, distribución, Estrecho de Magallanes, América del Sur, Región Subantártica.

\section{INTRODUCTION}

The Straits of Magellan (South America) (534' S Lat., 71³0'W Long.) represent one of the most interesting Subantarctic areas from both a biogeographical and an ecological point of view. The relative closeness of this area with the Antarctic continent, from which it is separated through the Scotia Arc, and the continuity with the American continent define the nature of biogeographic crossroads of this zone (Guzmán, 1992). This is well documented for both the benthic flora (Skottsberg, 1941) and the fauna (Brattström and Johanssen, 1983; Bastida et al., 1992). The peculiar hydrological conditions of the Straits, where different water bodies meet from the Atlantic and Pacific Oceans, that are also partially influenced by the Subantarctic currents of the Southern Ocean (Panella et al., 1991), contribute largely to its ecological importance as regards also the productivity of the pelagic system (Saggiomo et al., 1993; Magazzù et al., 1996). The hydrological regime of the Straits is a reflection of the complex geomorphological situation and bottom topography that also largely influence sediment features at large and medium scale (Brambati et al., 1991). These climatic, environmental and sedimentological features strongly influence the distribution and ecology of benthic organisms, and have great importance for the biogeographic and ecological comparison of bottom fauna with both the Antarctic and other Subantarctic areas.

In the framework of the Italian "Programma Nazionale di Ricerche in Antartide" (P.N.R.A.), the "Magellan Project" started in 1988 to promote geological, bio-ecological and oceanographic research in this important geographic area (Brambati, 1991). The first benthic survey within the Magellan Project was performed during the 2nd Italian Oceanographic cruise in February-March 1991 (Guglielmo, 1991). In this work we discuss the biodiversity, distribution and biogeography of polychaetes collected during that cruise. Polychaetes resulted, in fact, one of the most abundant groups of infaunal organisms of the macrozoobenthos collected from the soft bottoms of the Straits of Magellan. A preliminary study on their distribution is available in Mariani et al. (1996).
Past data on polychaetes of the Magellan region derive mainly from historical expeditions (see Rozbaczylo, 1985 for review). Among the most recent and important studies available for taxonomy and distribution at class and family level it is worth mentioning Wesenberg-Lund (1962), HartmannSchröder and Hartmann (1962, 1965), Hartman (1964, 1966, 1967, 1978), Orensanz (1990) for the order Eunicida, Blake (1983) for Spionidae, and Lana and Brémec (1994) for Sabellariidae. Some additional taxonomic and ecological information is available in Cantone (1990) and Sanfilippo (1994). A useful list of polychaetes from Chile, which also includes the Magellan region, is available in Rozbaczylo (1985), while for biogeographical comparisons the work of Knox and Lowry (1977) and Knox (1977) is still useful. Recently, Rozbaczylo et al. (1997), revising the past literature and adding data of a case study in the intertidal zones, gave a check list of 182 species of polychaetes reported up to date for the Magellan and Southern America Subantarctic regions.

\section{MATERIAL AND METHODS}

The material analyzed in this study was obtained during the 2nd Italian oceanographic cruise (February-March 1991) on board the R/V "Cariboo" (Guglielmo, 1991). Samples for both hydrological and benthic studies were collected over a large spatial scale from 24 stations distributed along the whole Straits of Magellan, from the Pacific Ocean mouth (st. 4) to the Atlantic Ocean (st. 26) (Fig. 1). A distinction of the two oceanic sides of the Straits has been based on the location of stations with respect to Cape Froward (arrow in Fig. 1), which represents the southernmost point of continental South America. Stations located westward of this point are considered as belonging to the Pacific sector, while those located eastward as belonging to the Atlantic sector. This distinction has only an operational value and does not imply any biogeographical separation between the two ocean sectors. On the other hand, the two oceanic sides of the Straits show such strong geomorphological and hydrographical differences that their distinction has an ecological significance. 


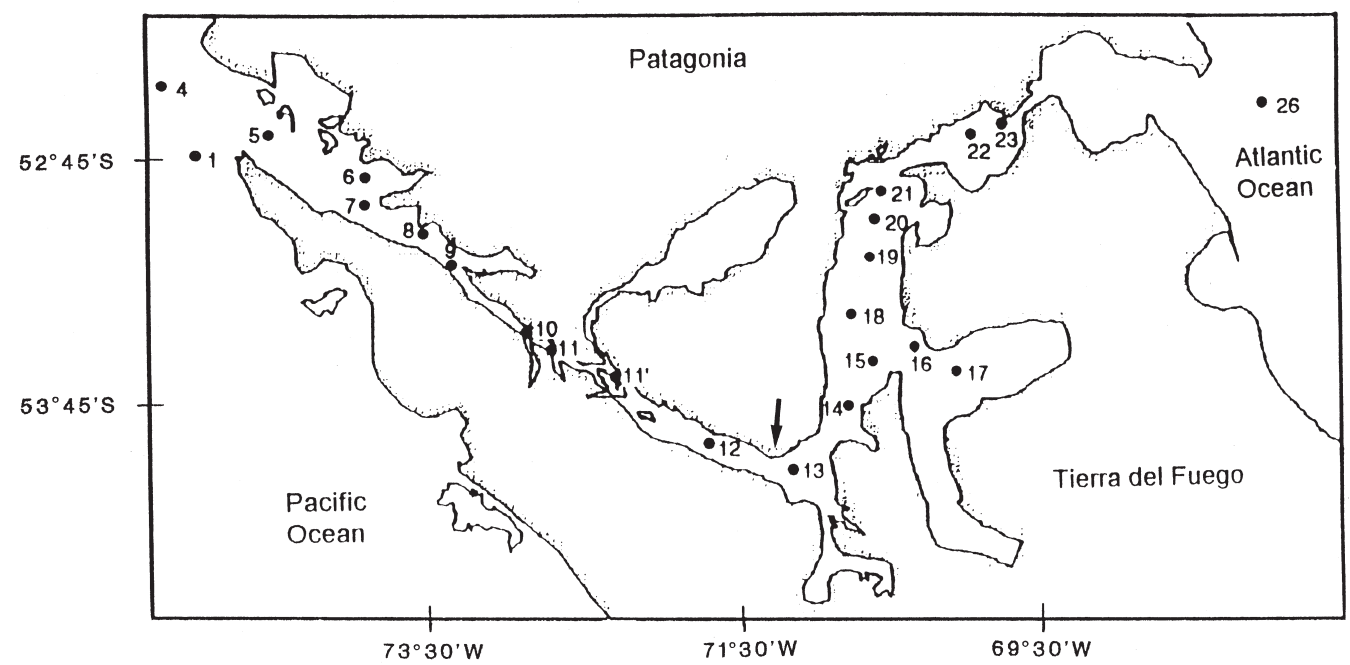

FIG. 1. - Map of the Straits of Magellan with the location of the sampling stations during the 2nd Italian Oceanographic cruise in March-April 1991. The distinction between Pacific and Atlantic sector is based on Cape Froward (arrow; see text).

Benthic organisms were sampled by means of different gears: rectangular (Charcot-Picard type) and triangular dredges and a van Veen grab (65 1; sampling surface: ca. $0.1 \mathrm{~m}^{2}$ ), within a depth range varying from $30 \mathrm{~m}$ to $1100 \mathrm{~m}$ (Table 1) (Mazzella and Gambi 1993). The van Veen grab was mainly used in the Pacific sector due to the greater depths and more complex geomorphology occurring in this part of the Straits. The use of the grab and its effectiveness in sampling was limited by some navigation and logistic problems on board. Both kinds of dredges (triangular and rectangular) were used mainly in the Atlantic sector of the Straits (Table 1). A visual evaluation of the sediment type or other substrate features of each station was performed on board and reported in the station logs as a characterization of the bottom (Mazzella and Gambi, 1993; Table 1). The biological material

TABLE 1. - List of all stations sampled with indication of depth, geographic coordinates, sampling gear used, sediment volume sampled, and substrate features visually recorded on board.

\begin{tabular}{|c|c|c|c|c|c|c|}
\hline Station & depth (m) & latitude & longitude & sampling gear & volume (1) & substrate features \\
\hline$* * 1$ & 100 & $5245^{\prime} \mathrm{S}$ & $7458{ }^{\prime} \mathrm{W}$ & Van Veen grab & 25 & coarse organogenous sand \\
\hline 4 & 80 & $5229^{\prime} \mathrm{S}$ & $7508^{\prime} \mathrm{W}$ & triangular dredge & - & organogenous remains \\
\hline$* 5$ & 175 & $5241^{\prime} \mathrm{S}$ & 7432 ' W & Van Veen grab & - & probably rocks \\
\hline 6 & 520 & $5251^{\prime} \mathrm{S}$ & 7354 ' W & Van Veen grab & 50 & dark green mud \\
\hline$* 7$ & 330 & $5256^{\prime} \mathrm{S}$ & $7357 \cdot \mathrm{W}$ & Van Veen grab & - & - \\
\hline$* * 7 a$ & 360 & $5257^{\prime} \mathrm{S}$ & $7357^{\prime} \mathrm{W}$ & Charcot dredge & - & - \\
\hline 8 & 800 & $5303^{\prime} \mathrm{S}$ & 7332 ' W & Van Veen grab & 5 & vulcanic rocks and sand \\
\hline$* 9$ & 1100 & $5311^{\prime} \mathrm{S}$ & $7320{ }^{\prime} \mathrm{W}$ & Van Veen grab & - & - \\
\hline 10 & 630 & $5325^{\prime} \mathrm{S}$ & $7252, \mathrm{~W}$ & Charcot dredge & 40 & gray-green clay and pebbles \\
\hline 11 & 515 & $53300^{\prime} \mathrm{S}$ & 7241 ' W & Van Veen grab & 40 & gray-green mud, sand and pebbles \\
\hline$* 11$ & 140 & $5336{ }^{\prime} \mathrm{S}$ & $7216^{\prime} \mathrm{W}$ & Van Veen grab & - & - \\
\hline 12 & 150 & $5348, \mathrm{~S}$ & $7149, \mathrm{~W}$ & Charcot dredge & - & pebbles \\
\hline 13 & 480 & $5356^{\prime} \mathrm{S}$ & $7105, \mathrm{~W}$ & Charcot dredge & 15 & dark green mud \\
\hline$* 14$ & 537 & 5343 'S & $7049{ }^{\prime} \mathrm{W}$ & Van Veen grab & 45 & dark green mud \\
\hline 15 & 460 & $5333^{\prime} \mathrm{S}$ & $7039^{\prime} \mathrm{W}$ & Van Veen grab & 50 & green mud \\
\hline 16 & $110-120$ & $5329^{\prime} \mathrm{S}$ & 7022 ' W & Charcot dredge & 85 & gravel, pebbles and mud \\
\hline 17 & 160 & 5334 ' S & 7004 W & Charcot dredge & 50 & muddy gravel and pebbles \\
\hline 18 & 170 & $5320{ }^{\prime} \mathrm{S}$ & $7043^{\prime} \mathrm{W}$ & Charcot dredge & 70 & muddy-sand, gravel and pebbles \\
\hline$* 19$ & - & $5308^{\prime} \mathrm{S}$ & $7038^{\prime} \mathrm{W}$ & Van Veen grab & - & - \\
\hline 20 & $75-80$ & 5300 's & $7032{ }^{\prime} \mathrm{W}$ & Charcot dredge & 60 & fine muddy-sand \\
\hline 21 & $70-80$ & $5252, \mathrm{~S}$ & $7032, \mathrm{~W}$ & Charcot dredge & 80 & sand, gravel and pebbles \\
\hline 22 & 35 & $5239^{\prime} \mathrm{S}$ & $6955, \mathrm{~W}$ & triangular dredge & 5 & gravel and pebbles \\
\hline 23 & $30-40$ & $5236^{\prime} \mathrm{S}$ & 6943 'W & triangular dredge & - & - \\
\hline 26 & $30-35$ & $5230, \mathrm{~S}$ & $6758 \cdot \mathrm{W}$ & $\begin{array}{l}\text { Van Veen grab + } \\
\text { Charcot dredge }\end{array}$ & 50 & mud with gravel and pebbles \\
\hline
\end{tabular}

* no benthos; **no polychaetes 
collected with all the gears used was sieved with 1 $\mathrm{mm}$ mesh screen, fixed in $4 \%$ formaldehyde and then preserved in alcohol $70 \%$. Polychaetes were counted and identified at the lowest taxonomic level possible. The classification at species level was often restricted by taxonomic problems within some families that need a thorough revision worldwide (e.g., Ampharetidae, Terebellidae), and in part by the poor condition of some of the collected specimens. For some of the Syllidae, the taxonomic analysis was limited to genus level due to their complex taxonomy and laborious processing. However, except for some Syllidae and a few other taxa, each taxon listed represents a single different species. Only the taxa classified at the species level were assigned to the biogeographical categories, according to the literature information (e.g., Knox, 1977; Rozbaczylo, 1985). Six main categories have been defined: Magellan-Subantarctic-Antarctic species (MSAn); Magellan-American (MAm), this category includes both the species endemic to the Magellan Straits and those distributed in the South American subcontinent; Magellan-Antarctic (MAn); Magellan-Subantarctic (MS), Cosmopolitans (C), and species with discontinuous distribution (D).

Due to the different sampling gears used along the Straits, the data did not allow a quantitative comparison of the stations. To study the qualitative faunistic similarity among stations, the Sørensen index was calculated. Stations 4 and 8 were excluded from the similarity analysis due to the occurrence of only 1 and 2 species, respectively.

\section{RESULTS AND DISCUSSION}

\section{Taxonomic and systematic considerations}

Polychaetes were collected at 16 stations of the 24 sampled (Table 1). A total of 1132 individuals (representing $35 \%$ of the infaunal abundance), belonging to 35 families and 119 taxa, were collected (Table 2). Only 49 taxa have been classified at the species level; the other taxa were identified at genus (39) or family (29) levels (Table 2). For 26 specimens, also the attribution at family level was also impossible. Except for the Syllidae, that still need a more detailed taxonomical analysis (see Methods), for most of the other undetermined species the systematic attribution was restricted by the fact that the collected specimens were incomplete or badly dam- aged, or belonged to poorly known genera that need a world-wide revision, to be properly classified. However, we provide indications related to the taxonomic attribution of some taxa that may be useful for future systematic analyses of polychaetes in the area.

\section{Cossura sp. 1}

The two specimens collected had only the first 20 chaetigers. A long palp originates from the 3rd chaetiger; this character, coupled with the chaetal morphology, suggests a close affinity with Cossura chilensis, a species already reported for this area (Rozbaczylo, 1985).

Cossura sp. 2

The only specimen collected is incomplete (19 setigers only); the palp originates from the 2nd chaetiger, the anterior notopodia have large acicular hairy chaetae. These features suggest an affinity with Cossura heterochaeta, species known for the Argentine continental shelf.

$$
\text { Prionospio (Prionospio) sp. }
$$

The loss of the 4th pair of branchiae prevents species identification. The lack of lateral wings in the peristomium restricts the possibilities to $P$. elhersi or $P$. orensanzi.

\section{Spiophanes sp.}

The specimens lack the posterior parapodia, impeding distintion between $S$. soederstroemi and $S$. kroyeri, while for the other features we could exclude $S$. tcherniai and S. bombyx.

Eulalia sp. 1 and Eulalia sp. 2

The specimens probably belong to two new species (F. Plejiel, pers. comm.).

\section{Phyllodoce (Anaitides) cf patagonica}

(Kinberg, 1866)

The specimens found show different colour pattern (homogeneous or in small stripes), but according to other features (eversible pharynx, shape of presetal lobes, dorsal cirri) they resemble the typical P. patagonica.

\section{Harmothoe spp.}

The analysis of the elitrae, which were all separated from the specimens found, indicates the presence of at least 3 different species.

\section{Harmothoe sp. 1}

The specimens found have some of the dorsal elitrae with a series of large vesicles on the outer rim; this feature suggests an affinity with the species $H$. spinosa.

\section{Podarkeopsis sp.}

The only specimen found could belong to a new species (F. Plejiel, pers. comm.). 
TABLE 2. - List of the polychaete taxa found at the studied stations along the Straits of Magellan.

\begin{tabular}{|c|c|c|c|c|c|c|c|c|c|c|c|c|c|c|c|c|}
\hline TAXA/SAMPLES & 46 & 8 & 10 & 111 & 12 & 1315 & 1516 & 17 & 18 & 202 & 21 & 22 & 23 & 26 & Total & Biogeo \\
\hline \multicolumn{17}{|l|}{ ORBINIIDAE } \\
\hline Leitoscoloplos kerguelensis (Mc Intosh,1885) & & & & & & & & & 1 & & & & & & 1 & MSAn \\
\hline Phylo felix (Kinberg) & & & & & & 1 & & & & & & & & 1 & 2 & MAn \\
\hline Scoloplos (Leodamas) ohlini (Ehlers, 1901) & & & & & & & & & & 21 & & & & & 21 & MSAn \\
\hline $\begin{array}{l}\text { PARAONIDAE } \\
\text { Tauberia gracilis (Tauber, 1879) }\end{array}$ & & & & & & & & & & & & & & 5 & 5 & C \\
\hline COSSURIDAE & & & & & & & & & & & & & & & & \\
\hline Cossura sp. 1 & & & 2 & & & & & & & & & & & & 2 & \\
\hline Cossura sp. 2 & & & & & & & & & & & & & & 1 & 1 & \\
\hline \multicolumn{17}{|l|}{ SPIONIDAE } \\
\hline Laonice cirrata (Sars, 1851) & & & & & & & 1 & & & & 1 & & & & 2 & C \\
\hline Laonice weddellia (Hartman, 1978) & & & & & & & 3 & 5 & 8 & & & & & & 16 & MAn \\
\hline Prionospio (Minuspio) sp. & & & & & & & & 24 & 9 & & & & & & 33 & \\
\hline Prionospio (Prionospio) sp. & & & & & & & & & & 3 & & & & & 3 & \\
\hline Rhyncospio glutea (Ehlers, 1897) & & & & & & & & & & & 1 & & & & 1 & MSAn \\
\hline Spiophanes sp. & & & & 1 & & & & 5 & 13 & & & & & & 19 & \\
\hline Spionidae gen. sp. 1 & & & & & & & & & & & & & & 1 & 1 & \\
\hline Spionidae gen. sp. 2 & & & & & & & & 2 & & & & & & 1 & 3 & \\
\hline \multicolumn{17}{|l|}{ CIRRATULIDAE } \\
\hline Dodecaceria multifiligera (Hartmann-Schröder, 1962) & & & & & & 2 & & 2 & 1 & & & & & & 5 & MAm \\
\hline Cirratulidae gen. sp. 1 & & & & & & & & & & & & & & 17 & 17 & \\
\hline Cirratulidae gen. sp. 2 & & & & & & & & & & & 3 & & & & 3 & \\
\hline CAPITELLIDAE & & & & & & & & & & & & & & & & \\
\hline Notomastus latericeus (Sars, 1851) & & & & & & & & 3 & 3 & & & & & 1 & 7 & $\mathbf{C}$ \\
\hline \multicolumn{17}{|l|}{ MALDANIDAE } \\
\hline Asychis amphiglypta (Ehlers, 1897) & 1 & 1 & 2 & & & & & & & & & & & & 3 & MSAn \\
\hline Axiothella minor (Arwidsson) & & & & & & & & & & & & & & 28 & 28 & MSAn \\
\hline Lumbriclymenella robusta (Árwidsson, 1911) & & & & 1 & & & & & & & & & & & 1 & MSAn \\
\hline Maldane sarsi (Malmgren, 1865) & 1 & 1 & 46 & & & & & 1 & 1 & & & & & & 49 & C \\
\hline Maldane sarsi antarctica (Arwidsson, 1911) & & & & 1 & 1 & 13 & 13 & & & & & & & & 15 & MSAn \\
\hline Rhodine antarctica (Gravier, 1907) & & & & & & & & 1 & & & & & & & 1 & MSAn \\
\hline \multirow{2}{*}{\multicolumn{17}{|c|}{$\begin{array}{l}\text { Maldanidae gen. sp. } \\
\text { OPHELIDAE }\end{array}$}} \\
\hline & & & & & & & & & & & & & & & & \\
\hline Ophelina gymnopyge (Ehlers, 1908) & & & & & & & & 4 & 4 & & & & & & 8 & MSAn \\
\hline Ophelina scaphigera (Ehlers, 1901) & & & & & & 1 & & 2 & & & & & & & 3 & MSAn \\
\hline Travisia kerguelensis (McIntosh, 1885) & & & & & & & & & & 3 & & & & & 3 & MSAn \\
\hline Travisia olens (Ehlers) & & & & & & & & & & 2 & & & & & 2 & MSAn \\
\hline SCALIBREGMATIDAE & & & & & & & & & & & & & & & & \\
\hline Scalibregmatidae gen. sp. & & 1 & & & & & & & & & & & & & 1 & \\
\hline PHYLLODOCIDAE & & & & & & & & & & & & & & & & \\
\hline Austrophyllum charcoti (Gravier, 1911) & & & 1 & & & & & & & & & & & & 1 & MSAn \\
\hline Eteone sp. & & & & & & & & & & & 1 & & & 1 & 2 & \\
\hline Eulalia picta (Kinberg, 1866) & & & & 1 & & & & & 1 & & & & & & 2 & MSAn \\
\hline Eulalia sp. 1 & & & & & & & & & & & 8 & & & 7 & 15 & \\
\hline Eulalia sp. 2 & & & & & & & & & & & 5 & & & 1 & 6 & \\
\hline Phyllodoce (Zverlinum) bulbosa (Wesenberg-Lund, 1962) & & & & & & & & & 1 & 2 & & & & & 3 & MAm \\
\hline Phyllodoce (Anaitides) cf. patagonica (Kinberg, 1866) & & & & & & & & 5 & & 2 & & & & & 7 & D \\
\hline Protomystides sp. & & & & & & & & 1 & & & & & & & 1 & \\
\hline POLYNOIDAE & & & & & & & & & & & & & & & & \\
\hline Harmothoe sp. 1 & & & & & & & & 2 & & & 15 & 2 & 5 & & 24 & \\
\hline Harmothoe spp. & & & & & & & 8 & & & & 27 & 7 & 5 & & 47 & \\
\hline SIGALIONIDAE & & & & & & & & & & & & & & & & \\
\hline Leanira quatrefagesi Kinberg, 1855 & & & & & & & & 3 & & & & & & & 3 & MAn \\
\hline Pholoe sp. & & & & & & 1 & & & & & 1 & & & 2 & 4 & \\
\hline HESIONIDAE & & & & & & & & & & & & & & & & \\
\hline Podarkeopsis sp. & & & & 1 & & & & & & & & & & & 1 & \\
\hline PILARGIDAE & & & & & & & & & & & & & & & & \\
\hline Ancistrosyllis groenlandica McIntosh, 1879 & & & & & & & & 1 & & & & & & & 1 & MSAn \\
\hline Ancistrosyllis sp. & & & & & & & & 1 & & & & & & & 1 & \\
\hline SYLLIDAE & & & & & & & & & & & & & & & & \\
\hline Autolytus charcoti (Gravier, 1906) & & & & & & & & & & & 21 & & & 15 & 36 & MSAn \\
\hline Exogone spp. & & & & & & & & & & & 67 & 1 & & 17 & 85 & \\
\hline Sphaerosyllis spp. & & & & & & & & & & & 25 & & 1 & 21 & 47 & \\
\hline Exogoninae gen. spp. & & & & & & & & & & & 28 & & & 3 & 31 & \\
\hline Amblyosyllis sp. & & & & & & & & & & & 1 & & & & 1 & \\
\hline Eusyllinae gen. sp. 1 & & & & & & & & & & & 14 & & & & 14 & \\
\hline Eusyllinae gen. sp. 2 & & & & & & & & & & & & & 1 & & 1 & \\
\hline Eusyllinae gen. sp. 3 & & & & & & & & & & & & & & 1 & 1 & \\
\hline Eusyllinae gen. sp. 4 & & & & & & & & & & & & & & 1 & 1 & \\
\hline Syllis sp. & & & & & & & & & & & 23 & & & & 23 & \\
\hline Trypanosyllis sp. & & & & & & & 3 & 2 & & & 32 & 5 & & 33 & 75 & \\
\hline
\end{tabular}


TABLE 2. (Cont.) - List of the polychaete taxa found at the studied stations along the Straits of Magellan.

Syllinae gen. sp. 1

Syllinae gen. sp. 2

Syllinae gen. sp. 3

Syllinae gen. sp. 4

NEREIDIDAE

Ceratocephale sp.

Gymnonereis sp.

Rullierinereis sp.

Websterinereis $\mathrm{sp}$

Nereididae gen. sp. 1

Nereididae gen. sp. 2

Nereididae gen. sp. 3

GLYCERIDAE

Glycera cf. papillosa Grube, 1857

Glycera sp. 1

Glycera sp. 2

GONIADIDAE

Glycinde armata (Kinberg, 1866)

NEPHTYIDAE

Aglaophamus sp. 1

Aglaophamus sp. 2

Nephtys imbricata Grube, 1857

Nephtyidae gen. sp.

SPHAERODORIDAE

Clavodorum sp.

Sphaerodoropsis sp. 1

Sphaerodoropsis sp. 2

AMPHINOMIDAE

Paramphinome australis Monro, 1930

Eurythoe cf. complanata (Pallas, 1766)

EUPHROSINIDAE

Euphrosine setosissima Ehlers, 1900

ONUPHIDAE

Kinbergonuphis dorsalis (Ehlers, 1897)

Onuphis pseudoiridescens Averincev, 1972

LUMBRINERIDAE

Abyssoninoe abyssorum (McIntosh, 1885)

Ninoe falklandica Monro, 1936

Lumbrineris cingulata (Ehlers, 1897)

Lumbrineris cf. cingulata (Ehlers, 1897)

Lumbrineridae gen. sp.

OENONIDAE

Drilonereis sp.

DORVILLEIDAE

Schistomeringos spp.

STERNASPIDAE

Sternaspis scutata (Renier, 1807)

SABELLARIIDAE

Idanthyrsus armatus (Kinberg, 1867)

PECTINARIIDAE

Cistenides ehlersi (Hessle, 1917)

AMPHARETIDAE

Ampharete kerguelensis (McIntosh, 1855)

Amphicteis gunneri antarctica (Hessle, 1917)

Anobothrus sp.

Melinna cristata (Sars, 1851)

Neosabellides sp.

Neosamitha gracilis (Hartman, 1967)

Samithella sp.

Sosanopsis sp.

Ampharetidae gen. sp. 1

Ampharetidae gen. sp. 2

Ampharetidae gen. sp. 3

Ampharetidae gen. sp. 4

Ampharetidae gen. sp. 5

Ampharetidae gen. sp. 6

Ampharetidae gen. sp. 7

TEREBELLIDAE

Artacama proboscidea (Malmgren, 1866)

Laena collaris (Hessle, 1917)

Pista corrientis (McIntosh, 1885)

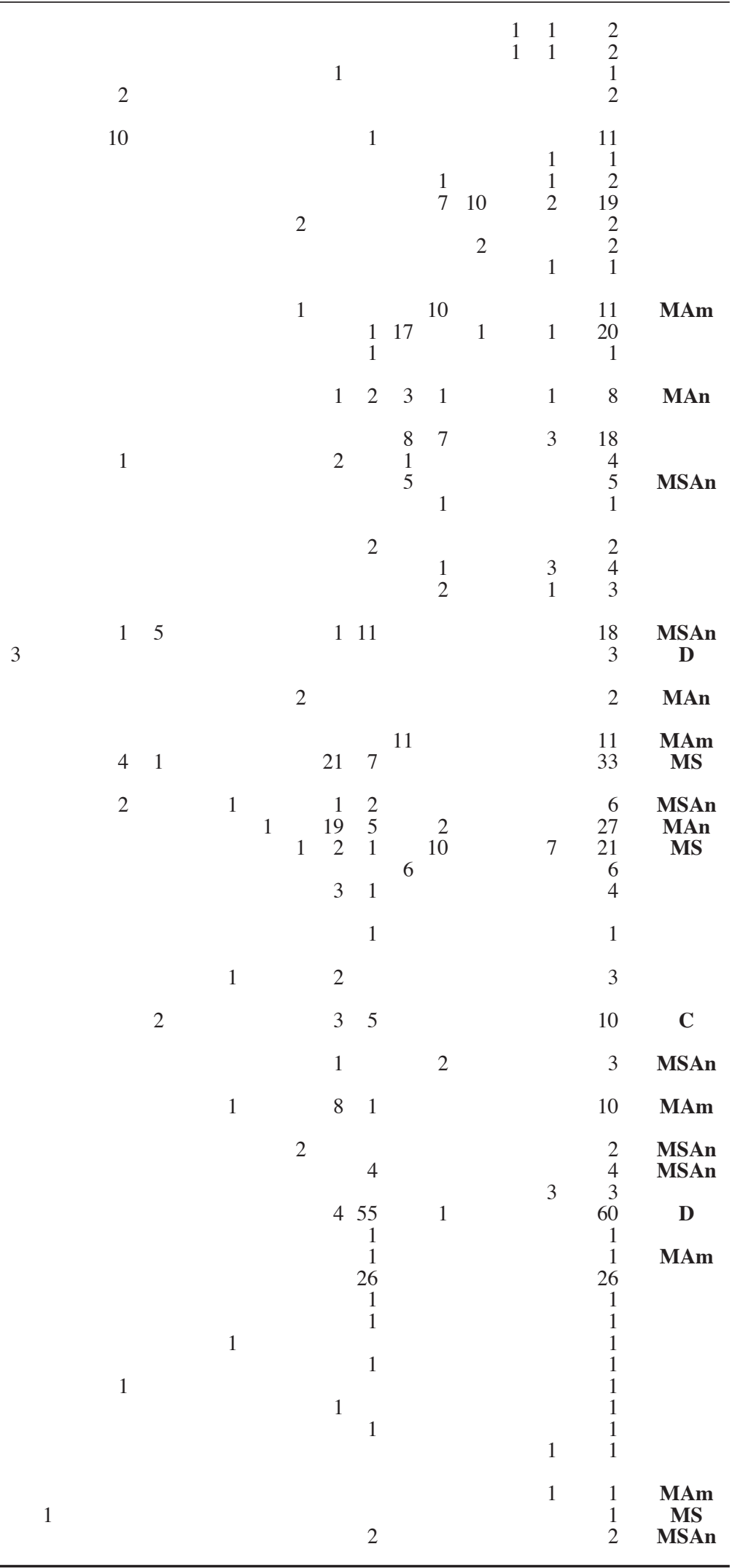


TABLE 2. (Cont.) - List of the polychaete taxa found at the studied stations along the Straits of Magellan.

\begin{tabular}{|c|c|c|c|c|c|c|c|c|c|c|c|c|c|c|c|c|c|c|}
\hline TAXA/SAMPLES & 4 & 6 & 8 & 10 & 11 & 12 & 13 & 15 & 16 & 17 & 18 & 20 & 21 & 22 & 23 & 26 & Total & Biogeo \\
\hline Pista sp. & & 1 & & 4 & & & & & & & & & & & & & 5 & \\
\hline Thelepus sp. & & & & & & & & & & & & & 1 & & & & 1 & \\
\hline Terbellidae gen. sp. & & & & & & & & & & & & & & & & 1 & 1 & \\
\hline TRICHOBRANCHIDAE & & & & & & & & & & & & & & & & & & \\
\hline Trichobranchus sp. & & & & & & & & & & 1 & & & & & & & 1 & \\
\hline SABELLIDAE & & & & & & & & & & & & & & & & & & \\
\hline Demonax sp. & & & & & & & & & & & & & 3 & & 1 & 1 & 5 & \\
\hline Euchone analis (Kroyer, 1856) & & & & & & & & & & 2 & 1 & & & & & & 3 & D \\
\hline Sabellidae gen. sp. & & & & & & & & & & 1 & & & & & & & 1 & \\
\hline SERPULIDAE & & & & & & & & & & & & & & & & & & \\
\hline Serpula narconensis (Baird, 1865) & & & & & & 1 & & & 5 & 1 & 1 & & 2 & & & & 10 & MSAn \\
\hline Unidentified & & & 1 & & 5 & & & & 2 & 6 & 6 & 2 & & 1 & 1 & 2 & 26 & \\
\hline
\end{tabular}

Ancistrosyllis sp.

$\mathrm{T}$ he only specimen found differs from A. groenlandica for the colour pattern, the beginning of the notopodial uncini and the shape of the prostomium. The other species of the genus reported for Chile is A. quellina.

\section{Aglaophamus sp. 1}

Most of the specimens found correspond well to the description of A. macrura by HartmannSchröder and Hartmann (1965) and WesenbergLund (1962). However, according to Hartman (1967), A. macrura described by HartmannSchröder and Hartmann (1965) actually corresponds to A. peruana.

\section{Aglaophamus sp. 2}

The specimens have the post-setal lobes very well developed, symmetrical and with an oval shape; the proboscis has 12 rows of papillae.

Drilonereis sp.

The only specimen found is very close to the description of Drilonereis sp. in Orensanz (1990).

Schistomeringos spp.

The three specimens found, even though incomplete, belong to this genus that according to Orensanz (1990) needs a general revision in the Southern hemisphere.

\section{Anobothrus sp.}

The presence of 15 thoracic and 12 abdominal segments, suggests an affinity with $A$. antarcticus. However, all members of Ampharetidae need a thorough revision.

\section{Melinna sp.}

Two specimens found in station 18 are surely different from both $M$. cristata and M. cristata australis (Hartmann-Schröder and Hartmann, 1965).

Neosabellides sp.

The only specimen found differs from the unique species of the genus known in Chile, $N$. elongatus. Samithella sp.

The genus is known for the Magellan region, however as all its members need a revision we preferred not to attribute the species name.

Sosanopsis sp.

The only specimen found shares many characters with the periantarctic species S. kerguelensis (Monro, 1939): absence of paleae, 12 uncinigerous segments, smooth tentacles. However, the branchial distribution pattern is different from that reported by Hartman (1966). The genus is new for the Straits of Magellan.

\section{Pista sp.}

The spiralled branchiae are similar to that of $P$. cristata. However, this species according to Hutchings P. (pers. comm.) has a boreal distribution, and the past attributions of austral specimens to this taxon probably refer to new species.

\section{Thelepus sp.}

The only specimen found is similar to the description of $T$. cincinnatus. However, $T$. cincinnatus, as P. cristata, is a species probably restricted to the boreal hemisphere and the past attributions of austral specimens to this taxon probably refer to new species (Hutchings P., pers. comm.).

\section{Biogeography, distribution and ecological considerations}

The following species: Axiothella minor, Melinna cristata, Laonice cirrata, Abyssoninoe abyssorum, Tauberia gracilis, Maldane sarsi antarctica, Asychis amphiglypta, Austrophyllum charcoti, Rhodine antarctica, Ophelina gymnopyge, Sternaspis scutata, Ampharete kerguelensis, Amphicteis gunneri antarctica, Neosamitha gracilis, Artacama pro- 
TABLE 3. - Values of the Sørensen similarity index among the studied stations along the Straits of Magellan. Stations 4 and 8 have been excluded from the analysis due to the occurrence of only 1 and 2 species, respectively. Values higher than 0.50 are indicated in bold.

\begin{tabular}{|c|c|c|c|c|c|c|c|c|c|c|c|c|c|c|}
\hline 6 & 1 & & & & & & & & & & & & & \\
\hline 10 & 0.37 & 1 & & & & & & & & & & & & \\
\hline 11 & 0 & 0.2 & 1 & & & & & & & & & & & \\
\hline 12 & 0 & 0 & 0.2 & 1 & & & & & & & & & & \\
\hline 13 & 0 & 0 & 0 & 0 & 1 & & & & & & & & & \\
\hline 15 & 0 & 0 & 0.2 & 0.5 & 0 & 1 & & & & & & & & \\
\hline 16 & 0 & 0 & 0 & 0.16 & 0 & 0 & 1 & & & & & & & \\
\hline 17 & 0.05 & 0.04 & 0.18 & 0.05 & 0.23 & 0.05 & 0.17 & 1 & & & & & & \\
\hline 18 & 0.04 & 0.04 & 0.11 & 0.05 & 0.13 & 0.05 & 0.13 & 0.52 & 1 & & & & & \\
\hline 20 & 0 & 0 & 0 & 0 & 0 & 0 & 0 & 0.12 & 0.12 & 1 & & & & \\
\hline 21 & 0 & 0 & 0 & 0.06 & 0.05 & 0.06 & 0.24 & 0.23 & 0.14 & 0.09 & 1 & & & \\
\hline 22 & 0 & 0 & 0 & 0 & 0 & 0 & 0.23 & 0.09 & 0.04 & 0.1 & 0.25 & 1 & & \\
\hline 23 & 0 & 0 & 0 & 0 & 0 & 0 & 0.12 & 0.04 & 0 & 0 & 0.2 & 0.28 & 1 & \\
\hline \multirow[t]{2}{*}{26} & 0 & 0 & 0 & 0 & 0.26 & 0 & 0.23 & 0.14 & 0.18 & 0.3 & 0.82 & 0.43 & 0.57 & 1 \\
\hline & 6 & 10 & 11 & 12 & 13 & 15 & 16 & 17 & 18 & 20 & 21 & 22 & 23 & 26 \\
\hline
\end{tabular}

boscidea, Laena collaris, Euchone analis, have been recorded for the first time in the Straits of Magellan during this survey. Taking in to account the collection of three potential new species (see above systematic considerations) and of a new genus (Sosanopsis), a total of 21 taxa can be considered as new records for the studied area.

The biogeographic analysis, conducted only on the taxa classified at the species level (49, see Table 2), showed the dominance of Magellan-Subantarctic-Antarctic species (MSAn, 50\%), followed by
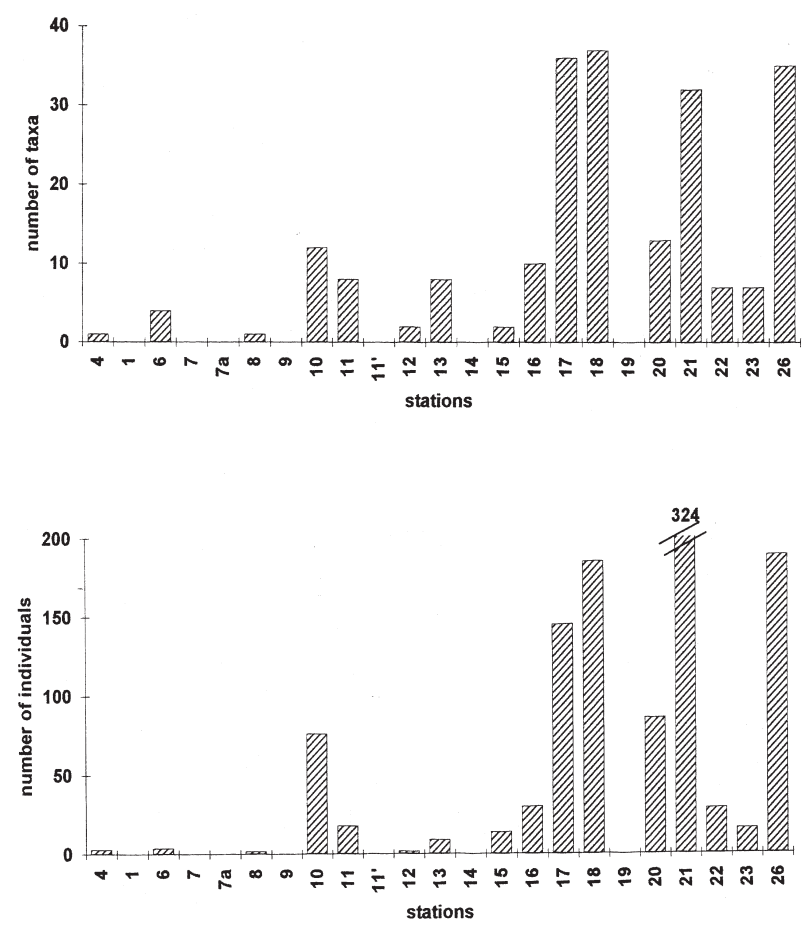

FIG. 2. - Trends of the total number of polychaete taxa (above) and of individuals (below) collected from the studied stations along the Straits of Magellan (stations where no benthos or polychaetes were found are also reported in the $\mathrm{X}$-axis).
Magellan-American (MAm, 14\%), MagellanAntarctic (MAn, 12\%), Magellan-Subantarctic (MS, $6 \%)$, Cosmopolitans (C, 10\%) species, and also by a few species with discontinuous distribution $(\mathrm{D}, 8 \%)$. Most of the taxa, including the more abundant ones, showed a very localized distribution only in a single or a few stations (e.g., Scoloplos ohlini, Axiothella minor, Melinna cristata, Autolytus charcoti, Onuphis pseudoiridescens). The Sørensen similarity index showed, in fact, very low values (below 0.30) among all stations (Table 3), except for a few samples such as st. 21 and st. $26(\mathrm{~S}=0.82)$, st. 26 and st. $23(\mathrm{~S}=0.57)$, and st. 17 and st. $18(\mathrm{~S}=0.52)$.

The maximum number of individuals and of taxa ( $81 \%$ of the total) has been observed in some stations located in the Atlantic sector of the Straits (st. 17, 18, 21 e 26), while in the Pacific sector both species richness and abundance were very low (Fig. $2 \mathrm{a}$ and $2 \mathrm{~b}$ ), especially in stations 4 and 8 which were represented only by 1 and 2 species, respectively. Among the most diverse stations of the Atlantic sector, both stations 17 and 18 were characterized by a muddy sand mixed with gravel and pebbles, the most abundant species were represented by Prionospio (Minuspio) sp., Spiophanes sp., Paramphinome australis, Onuphis pseudoiridescens, Ninoe falklandica, Neosabellides sp., and Samithella sp. Station 21 was characterized by a mixture of sand, gravel and pebbles and by the presence of biogenic debris deriving from a conspicuous thanatocoenosis of the bivalve Zygochlamys patagonica (Di Geronimo et al., 1991, 1992). In these stations the polychaete assemblage was composed of species typical of soft sediments, as well as of epibenthic (e.g., Harmothoe spp., Idanthyrsus armatus), and interstitial (e.g., Exogone spp., Sphaerosyllis spp.) forms. Furthermore, a few other polychaete species belonging 
to Serpulidae and Spirorbidae have been reported by Sanfilippo (1994) as epibionts on the valves of the Zygochlamys. Finally, station 26 characterized by a muddy sediment mixed with gravel and pebbles, showed an assemblage very similar to that of st. 21 , but with the abundance also of the burrower maldanid Axiothella minor, probably linked to the fine fraction. Some species, even though not very abundant and locally distributed, seemed related to the occurrence of a typical sediment structure, such as the two closely related maldanids Maldane sarsi and $M$. sarsi antarctica at the muddy stations 10 and 15 (Table 2).

On the whole, the polychaete species richness recorded during this survey along the Straits was relatively high, considering the low number of stations studied and of the individuals collected. Furthermore, compared to previous knowledge about polychaetes of this Subantarctic area, that reported a total of 182 species (Rozbaczylo, 1985; Rozbaczylo et al., 1997), our results are remarkable, and they contribute to increase the number of species known for this zone to more than 200 taxa.

The biogeographical analysis showed a low degree of endemism for polychaetes in the Magellan region, compared to isopods (Mariani et al., 1996), and a higher affinity with the truly Antarctic Province, as observed for sponges (Sarà, 1992). However, this picture may be biased by the relatively low number of species determined (49), from a total of 119 taxa found.

The trends observed for both number of species and individuals along the Straits (Pacific versus Atlantic sector) seem due to the bias introduced by the different sampling gears used in the two sectors of the Straits (see Methods). Similar trends have been observed also for the isopods collected at the same stations (Lorenti and Mariani, 1997), and which are more mobile than polychaetes.

The high species richness found, coupled with the low values of faunistic similarity among the stations, suggests that the soft bottoms of the Straits of Magellan show, at the investigated spatial scale, a mosaic of highly diversified biotopes (Mariani et al., 1996; Lorenti and Mariani, 1997). This may be due to various factors such as the wide geographic area investigated, the wide bathymetric range sampled, and the different sampling gears used. This situation is well synthesized in st. 21 where the presence of a coarse, biodetritic component (Zygochlamys thanatocoenosis) in the sediment favours the occurrence of a rich and diversified polychaete fauna. A similar pattern of species diversification at this scale has also been recorded with the bryozoan (Rosso and Sanfilippo, 1991; Moyano, 1992), molluscan (Di Geronimo et al., 1992) and isopod assemblages (Lorenti and Mariani, 1997).

The pattern of species richness herein reported, even though mainly recognizable at the moment only along the Atlantic sector of the Straits, confirms that both composition and diversification of the polychaete assemblages are related to sediment heterogeneity and bottom structural complexity. This is a quite common feature for polychaete populations, and has been recorded also in high Antarctic soft bottoms (Gambi et al., 1997).

\section{ACKNOWLEDGEMENTS}

Thanks are due to Dr L. Mazzella (Stazione Zoologica di Napoli) who participated in the collection and preliminary processing of the samples on board of the R/V "Cariboo". We also wish to thank Prof. Cantone G. (University of Catania, Italy) for help in the classification of some species belonging to various families of Sedentaria, and Dr. F. Pleijel (Swedish Museum of Natural History, Stockholm) for checking the classification of Hesionidae and Phyllodocidae. We are also grateful to Dr. C. Brémec (INIDEP, Mar del Plata, Argentina) and Prof. N. Rozbaczylo (Pontificia Universidad Católica de Chile, Santiago) for critical reading and useful suggestions. This research has been conducted in the framework of the "Magellan Project" funded by the Progetto Nazionale di Ricerche in Antartide (P.N.R.A.).

\section{REFERENCES}

Bastida, R., A. Roux and D.E. Martinez. - 1992. Benthic communities of the Argentine continental shelf. Oceanol. Acta, 15 (6): 687-698.

Blake, J.A. - 1983. Polychaetes of the family Spionidae from South America, Antarctica, and adjacent seas and islands. Biology of the Antarctic Seas XIV, Antarct. Res. Ser., 39 (3): 205-288.

Brambati, A. - 1991. Introduction to the Magellan Project. Boll. Oceanol. Teorica Appl., 9 (2-3): 83-92.

Brambati, A., C. Fontolan and U. Simeoni. - 1991. Recent sediments and sedimentological processes in the Strait of Magellan. Boll. Oceanol. Teorica Appl., 9 (2-3): 217-259.

Brattström, H. and A. Johanssen. - 1983. Ecological and regional zoogeography of the marine benthic fauna of Chile. Sarsia, 68: 289-339.

Cantone, G. - 1990. Due nuove specie di Anellidi Policheti della Terra del Fuoco. Animalia, 17: 55-60.

Di Geronimo, I., S. Privitera and C. Valdovinos. - 1991. Molluscan thanatocoenoses of the Magellan Strait. Nat. Sc. Com. Ant., Magellan Cruise, February-March 1991. Data Rep. (1993) II: 297-306. 
Di Geronimo, I., S. Privitera and C. Valdovinos. - 1992. Molluscan thanatocoenoses of the Magellan Strait. Mem. Biol. Mar. Oceanogr., 19 N.S.: 205-208.

Gambi, M.C., A. Castelli and M. Guizzardi. - 1997. Polychaete populations of the shallow soft bottoms off Terra Nova Bay (Ross Sea, Antarctica): distribution, diversity and biomass. Polar Biol., 17: 199-210.

Guglielmo, L. - 1991. Stretto di Magellano. Campagna di oceanografia fisica, chimica e biologica (Febbraio-Marzo 1991) (N/O Cariboo). Mem. Biol. Mar. Oceanogr., 19 N.S.: 33-41.

Guzmán, L. - 1992. Visión panorámica sobre los ambientes terrestres y acuáticos de Magallanes $\left(49^{\circ}-56^{\circ} 30^{\prime} S\right)$. In: V.A. Gallardo, O. Ferretti and H.I. Moyano (eds), Oceanografia in Antartide, pp. 479-591. Ediciones Documentas, Santiago.

Hartman, O. - 1964. Polychaeta Errantia of Antarctica. Antarct. Res. Ser., 3: 1-131.

Hartman, O. - 1966. Polychaeta Myzostomidae and Sedentaria of Antarctica. Antarct. Res. Ser., 7: 1-158.

Hartman, O. - 1967. Polychaeta Annelida collected by the USNS Eltanin and Staten Island cruises, chiefly from the Antarctic Seas. Allan Hancock Monogr. mar. Biol., 2: 1-397.

Hartman, O. - 1978. Polychaeta from the Weddell Sea quadrant, Antarctica. Biology of Antarctic seas VI. Antarct. Res. Ser., 26: 125-223.

Hartmann-Schröder, G. and G. Hartmann. - 1962. Zur Kenntnis des Eulitorals der chilenischen Pazifikküste und der argentinischen Küste Südpatagoniens unter besonderer Berücksichtigung der Polychaeten und Ostracoden. Mitt. Hamb. Zool. Mus. Inst., 60: 57-167.

Hartmann-Schröder, G. and G. Hartmann. - 1965. Zur Kenntnis des Sublitorals der chilenischen Küste unter besonderer Berücksichtiung der Polychaeten und Ostracoden. Mitt. Hamb. Zool. Mus. Inst., 62: 59-305.

Knox, G.A. - 1977. The Antarctic polychaete fauna: its characteristics, distribution patterns, and evolution. In: G.A. Llano (ed.), Adaptation within Antarctic Ecosystem, Proc. III SCAR Symp. Antarct. Biol., pp. 1111-1127. Smithsonian Institution, Washington D. C.

Knox, G.A. and J.K. Lowry - 1977. A comparison between the benthos of the Southern Ocean and the North Polar Ocean with special reference of the Amphipoda and the Polychaeta. In: M.J. Dunbar (ed.), Polar Oceans, pp. 423-462. Arctic Institute of North America, Calgary.

Lana, P. and C. Brémec. - 1994. Sabellariidae (Annelida, Polychaeta) from South America. Actes de la $4^{\circ}$ Conférence Internationale des Polychètes. Mém. Mus. Nat. Hist. Nat., 162: 209-221.

Lorenti, M. and S. Mariani. - 1997. Isopod assemblages in the Strait of Magellan: structural and functional aspects. Polar Biol., 18: 254-259.

Magazzù, G., S. Panella and F. Decembrini. - 1996. Seasonal variability of fractionated phytoplankton, biomass and primary pro- duction in the Strait of Magellan. J. Mar. Syst., 9: 249-267.

Mariani, S., M. C. Gambi, M. Lorenti and L. Mazzella. - 1996. Benthic populations of the soft bottoms in the Strait of Magellan (Southern America): biodiversity, distribution and biogeography of polychaetes and crustacean isopods. Biol. Mar. Medit., 3 (1): 155-158.

Mazzella, L. and M.C. Gambi. - 1993. First oceanographic cruise in the Strait of Magellan (February-March 1991): Report on benthic populations of the intertidal zone of the "Seno" Skyring. Nat. Sc. Com. Ant. Magellan Cruise, February-March 1991. Data Report II: 283-296.

Moyano, H.I. - 1992. Bryozoa de la expedición italiana al Estrecho de Magallanes Febrero-Marzo 1991: evaluación preliminar. In: V.A. Gallardo, O. Ferretti and H.I. Moyano (eds.), Oceanografia in Antartide, pp. 509-516. Ediciones Documentas, Santiago.

Orensanz, J.M. - 1990. The Eunicemorph polychaete annelids from Antarctic and Subantarctic seas. Antarct. Res. Ser., 52: 1-183.

Panella, S., A. Michelato, R. Perdicaro, G. Magazzù, F. Decembrini and P. Scarazzato. - 1991. A preliminary contribution to understanding the hydrological characteristics of the Strait of Magellan: Austral Spring 1989. Boll. Oceanol. Teorica Appl., 9(2-3): 107-126.

Rosso, A. and R. Sanfilippo. - 1991. Epibionts distribution pattern of Chlamys patagonica (King and Broderip) of the Magellan Strait. Mem. Biol. Mar. Oceanogr., 19: 237-240.

Rozbaczylo, N. - 1985. Los Anélidos Poliquetos de Chile. Monogr. Biol., 3: 1-284

Rozbaczylo, N., C. Ríos and E. Mutscke. - 1997. Poliquetos de la región de Magallanes: estado actual de su conocimiento a través de un análisis histórico y un estudio de caso. Abstracts of the IBMANT'97. Punta Arenas (Chile), 7-11 de Abril, 1997, p.75.

Saggiomo, V., A. Goffart, G.C. Carrada and J.H. Hecq. - 1993. Spatial patterns of phytoplanktonic pigments and primary production in a semi-enclosed periantarctic ecosystem: the Strait of Magellan. J. Mar. Syst., 5: 119-142.

Sanfilippo, R. - 1994. Polychaete distribution patterns on Chlamys patagonica of the Magellan Strait. Actes de la $4^{\circ}$ Conférence Internationale des Polychètes. Mém. Mus. Nat. Hist. Nat., Paris, 162: 535-540.

Sarà, M. - 1992. I poriferi nell'ecosistema Antarctico: la Provincia Magellanica. In: V.A. Gallardo, O. Ferretti and H.I. Moyano (eds), Oceanografia in Antartide, pp. 517-522. Ediciones Documentas, Santiago.

Skottsberg, C. - 1941. Communities of marine algae in Subantarctic and Antarctic waters. Kungl. Sv. Vett. Akademiens, Handligar., 19(4): 1-92.

Wesenberg-Lund, E. - 1962. Polychaeta Errantia. Reports of the Lund University Chile Expedition 1948-49. Lunds Univ. Årsskr. N.F. Avd. 2, Bd. 57, 12: 1-138. 